\title{
Paperless Smart Classroom Attendance System Using Fingerprint Biometric With SMS Through Rapid Application Development Tool
}

\author{
Carldwight O. Ocumen ${ }^{1}$, Jenefer P. Bermusa ${ }^{2}$, Mary Jane R. Laranang ${ }^{3}$, \\ Edward B. Panganiban ${ }^{4}$, Sandy E. Laranang ${ }^{5}$ \\ ${ }^{1,2,3}$ AMA Computer College, Santiago City, Isabela, Philippines \\ ${ }^{4}$ Isabela State University, Echague, Isabela, Philippines \\ ${ }^{5}$ Quirino State University, Diffun, Quirino, Philippines \\ carldwight23@gmail.com ${ }^{1}$, jenbermusa@gmail.com ${ }^{2}$, maryjanelaranang@ gmail.com ${ }^{3}$, \\ ebpanganiban@isu.edu.ph ${ }^{4}$, halflife1104@yahoo.com ${ }^{5}$
}

\begin{abstract}
As people's demand and lifestyle change, the demand for advancing the type of technology used is high. This study aims to provide a computerized system that will be able to provide an accurate, reliable, convenient, timely, and with less cost paperless attendance system in the classroom. The system established is real-time monitoring of student attendance with SMS notifications to parents or guardians. The SMS would serve as a notification if the student went to his or her classes. The system has undergone methods and procedures as well as several tests to obtain the desired outputs. In developing the software, the Rapid Application Development approach was used particularly, VB.NET as the frontend and MySQL on the backend. System development processes were used as a guide in establishing the system. These include conceptualization of the system software, designing of the system software, and implementation and testing of the system software. The results shown in the several tables of tests have proven that the system performs its functions well. Respondents, which include IT experts, have also proven that the system is reliable, functional, and usable.
\end{abstract}

Key words: Paperless,fingerprint biometric, SMS, attendance system, rapid application development

\section{INTRODUCTION}

People from the academe have long emphasized the significance of class attendance. Only in the classroom may the student hear the teacher's lessons, participate in class discussions, and enjoy the benefits of impulsive interactions between the teacher and student. Attendance sheets consume large amounts of paper with this process. It is not a surprise that students with high absence amounts earn lower grades than students with better attendance. Student absenteeism has been a major problem for schools, so authors have conceptualized a system that takes full automation in monitoring attendance of students using biometric techniques without using paper to show the proof. Passwords or smartcards have been the most broadly utilized authentication techniques because of simple execution and substitution; in any case, remembering a secret key or conveying a smartcard, or dealing with numerous passwords/smartcards for the various system is an overhead to users. Also, they are misleadingly connected with clients and can't genuinely recognize people. All the more truly, they can be lost or stolen, bringing about fake and other security breaks. Therefore, biometrics is turning into a promising confirmation/recognizable proof strategy since it ties a person with his character and defeats the primary deficiencies natural in the utilization of passwords and smartcards. Biometrics has been broadly utilized and embraced as a promising authentication technique because of its points of interest over some current strategies, especially its protection from misfortunes brought about by theft of passwords and smartcards [1].

Biometric techniques are widely used in various areas like iris recognition, voice identification, fingerprint identification, and DNA recognition [2] [3]. A fingerprint is an impression of the friction ridges on all parts of the finger. A friction ridge is a raised portion of the epidermis on the palm, fingers, and toes. Consisting of one or more connected ridge units of friction ridge skin. The term fingerprint is referring impression transferred from the pad the last joint of fingers and thumbs, though fingerprint cards also typically record portions of lower joint areas of the fingers, which also used to make identifications. It is believed that no two people have an identical fingerprint in the world, so the fingerprint verification and identification is a most popular way to verify the authenticity or identity of a person wherever of the security is a problematic question. The reason for the popularity of the fingerprint technique is the uniqueness of a person arises from his behavior [4]. Fingerprint authentication is a standout amongst the most famous and advertised biometrics technologies. As a result of their uniqueness and consistency after some time, fingerprints have been being used for ID for over a century, all the more as of late getting to be automated because of developments in Information Technology abilities [5]. It has been 
demonstrated throughout the years that the fingerprints of every single individual are distinct [6].

The current approach in which manually taking attendance and maintaining the attendance records is a very inconvenient task. Student attendance is a must; inconsistent attendance is a major problem for most of the schools here in the Philippines. In the current system, the instructor takes attendance of students each class, passing on attendance sheets or a roll call to students; thus, it is very unreliable because some of the students take attendance and leave the room. It also lessens the time for the lecture. As a result, the manual checking of attendance becomes prone to human error, time-consuming, and costly for the institution (Shoewu and Idowu 2012). Dealing with the attendance information of such a vast gathering is additionally exceptionally troublesome. Another drawback of the present system is the chance for the students to check fake attendance [8]. This unique mark based gadgets are being utilized as a part of professional workplaces. These gadgets utilize PC to store and check fingerprints. It can be ported to scholarly conditions with some changes [9].

Paper production causes deforestation and man-made climate change and produces greenhouse gases from the air pollution produced. Aside from this, printing inks and toners are very expensive and use environment-damaging volatile organic compounds, heavy metals, and non-renewable oils. [10]. In $2017,40 \%$ of the world's industrial logging went toward the paper manufacturing process. Paper production is the third most energy-intensive of all manufacturing industries, for it uses $12 \%$ of the total energy in the industry. Twenty-four thousand kilograms of paper waste hit landfills in the United States every 12 months. 16\% of landfill space is filled by paper products, which leads to a greenhouse gas of 23 times more potent than carbon dioxide. China and the United States are some of the top consumers globally of paper and cardboard products. China generates nearly 108 billion kilograms of paper in 2014 [11].

In the Philippines, the academic sector that uses all types of examinations is printed on paper. They run from 4 to 5 pages, with the number of students, the number of courses, and the number of terms in a year, 10 billion $\mathrm{kg}$ of paper are used every year. An on-going study of paper used in one of the colleges in Metro Manila is an example. For one of its departments alone, initial estimates show that for examinations alone, use 1.8 million sheets of paper (more than 3,500 reams) annually. The end-term requirements account for additional consumption of another 1,000 reams of paper. Almost 2.5 million sheets of paper $(5,000$ reams) annually for one department alone [12]. According to a study, for every $55,000 \mathrm{~kg}$ of paper reduced, it will save 1,000 trees, $84 \mathrm{~m}^{3}$ of oil, 2,400,00 kW of energy, and $1,600 \mathrm{~m}^{3}$ of water from paper production [11]. Thus, going paperless can reduced paper production. The paperless process is the conversion of paper documents into digital form to save money, boost productivity, save space, make documentation and information sharing easier, keep personal information more secure, and, most especially it helps the environment
[10] [13]. Going paperless, streamlined the process of receiving, evaluating, and returning written work [14]. The resulting technologies are typically called green technologies. A great demand for paper may lead to the destruction of large quantities of trees, which may have a negative impact on the environment. As a result, computer users are typically encouraged to reduce the amount of paper utilized for printing by scaling multiple pages down to a single page [15]. Benefits of going green include reduced costs and quicker access to information, more space, document security and easy information sharing, access anywhere and electronic prescriptions, less paper in, less temporary paper, and less paper out [10].

Today, a paperless classroom is being developed wherein faculty and students exchange information and assignments electronically. It is designed to improve the efficiency of the learning experience, to contribute to asynchronous learning, and to help students develop the electronic skills and competencies they will need. [16]. The researchers based their system design on the features of the related studies mentioned and described although developing a higher version of a computerized attendance monitoring system and using biometrics thru the fingerprint and adding an SMS [17], [18], [19] Notification to the parents who assured that their children come to school regularly. The system focuses on the accuracy of data, efficiency of the software, and reliability of the system resources and functionalities, however maintaining the quality of service in terms of speed in accessing and retrieving data from the system. It also provides a higher level of security that eliminates data redundancy, time fraud, and unauthorized access by providing the unique identity of the users. The study enables the instructor to check his/her students' attendance, consequently by utilizing (PC) with no additional cost and exertion. Thus, the user needs to spare the attendance in the memory so as to utilize it for future reference [20]. Another model of a Classroom Attendance Management System (CAMS) is produced that utilizations unique finger impressions as a biometric highlight for classroom attendance. The CAMS comprises of modules for database, web-UI, and perspectives at different levels of access. Fingerprints are put away progressively in a database for figuring the diverse insights [21]. Numerous colleges utilize paper-based or smart card technology to check the attendance of students. Different systems have been developed for colleges without considering late issues; however, this venture, dissimilar to the current plans, is endeavoring to enhance information exactness by including a unique mark based enlist and utilizing a progression of systems to give a solid, ideal, and precise recognizable proof strategy [22].

The system is intended at any school, particularly for the elementary school in real-time monitoring of student attendance with SMS Notifications to parents and is notified if the student really went to school. The system was developed using VB.NET as the frontend and SQL on the backend. The system would be reliable in terms of monitoring of attendance thru the use of a fingerprint. Upon registering a student record (USN, Full Name, Guardian Number, Image, Fingerprint), a 
text confirming the registration in the system is then sent in the guardian's contact number, and upon entering the campus premises (school classroom), the system would send a real-time report of the IN and OUT of the student. The system would also tighten the security upon entering the campus because the system would invalidate unenrolled fingerprints. The system also generates an Attendance Log for future use. The system provides information that is accurate, reliable, convenient, timely, and with less cost.

This paper focused on the development of a "Paperless Smart Classroom Attendance System using Fingerprint Biometric with SMS through Rapid Application Development Tool." This is intended to replace the current process that is being used. It is also designed and worked into code to reduce time wasted on manual checking of attendance and errors in encoding it. The system is designed using the server-client architecture. The created system had diminished the work in taking the attendance of students manually. It decreased the time and save heaps of labor. The system automates the attendance system by examining the fingerprints of the students and generating the reports of the attendance. This system has a high level of security to avoid the loss of data. Then data is then stored in a database [23]. A student's attendance recording study is conducted effectively. Toward the start of each class, attendance is confirmed by the fingerprint of a particular instructor; at that point, students enlist their attendance, and the end of the address is additionally validated by fingerprint biometrics of the subject instructor, so the system is much dependable and precise. It additionally demonstrates the aggregate time for which the teacher has attended the class. PC communication generates attendance based on the required format. Conveying through the GSM module updates all data to higher management and was able to send the information to all guardians or parents every week [24].

\section{MATERIALS AND METHODS}

The fingerprint Identification System utilized for identification of students is speedier in execution than some other unique finger impression distinguishing proof frameworks. This undertaking chiefly involved the advancement of the attendance management system and unique mark distinguishing proof framework. Attendance management is exceptionally useful in sparing a profitable time of students and instructors, paper, and producing a report at the required time. This venture introduced a system utilizing which attendance management can be automated and online (Mishra and Trivedi 2011).

\subsection{The Conceptual Framework}

The conceptual framework was established by determining the status of the current attendance checking system. The current and common problems the respondents encountered on the current attendance monitoring process were identified. Then, the researchers created questionnaires based on the international standard in evaluating software quality ISO/TEC 25010:2011. Then, the processes of the manual system and the problems encountered were determined by asking their idea and experiences. The current system is simplified through Figure 1. The conventional checking of attendance of students is shown in Figure 1. As shown in the Figure, the teacher calls the name of the students one by one, then the student would respond to the teacher by raising their hand. After that, the teacher records the attendance of the students on the attendance sheet.

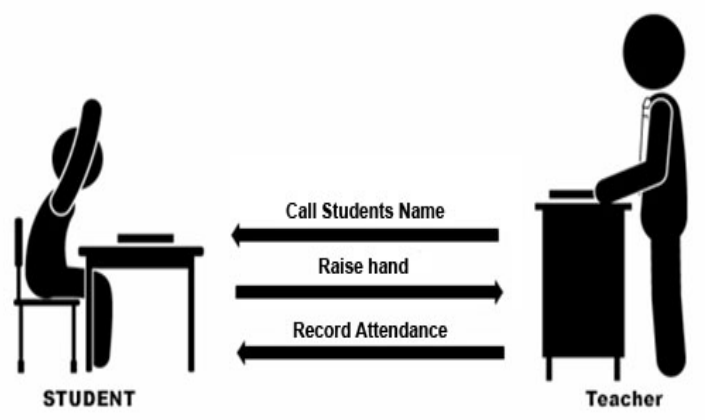

Figure 1: Current Process flow of monitoring or checking of attendance

The researchers analyzed all the gathered information and idea about the current system. After analyzing all the gathered ideas and information of the manual system, the researchers conceptualized a system entitled "Paperless Smart Classroom Attendance System using Fingerprint Biometric with SMS through Rapid Application Development Tool." Those are the concepts that are used by the researchers and served as a guide in planning, designing, determining the functions, in developing and implementing the system. The system takes attendance of every student by constant monitoring at the entrance and exit points. The consequence of the initial experiment demonstrated enhanced execution in the estimation of the attendance in contrast to the conventional attendance system (Kar et al. 2012). Biometrics presents clear preferences over a secret key and token-based security. The review thinks about different issues identified with uni-modal biometric frameworks is talked about. The security and protection worry that biometric confirmation raises should be addressed to [27]. Of all the biometric frameworks accessible, unique finger impression confirmation is the most prevailing in commercial applications because of its brilliant execution and minimal cost (Cruz et al. 2015). Hence, the conceptual framework of the system was determined as represented in Figure 2.

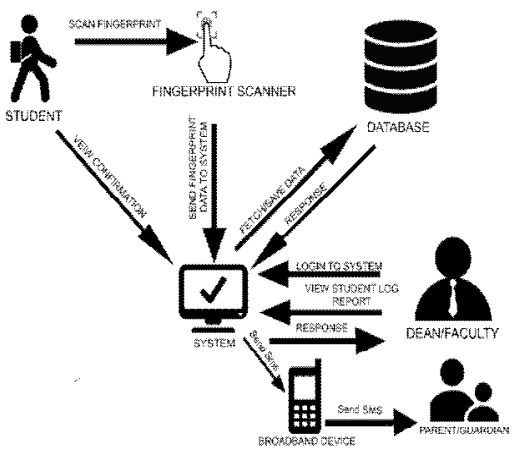

Figure 2: Conceptual framework of the developed system 
Figure 2 shows the concept of the whole process. The system software is controlled by the system administrator as well as registration of student accounts. The Figure also shows the process flow of the student's participation in the system. The system administrators need to log-in to the system to register student's accounts. The accounts registered are stored in the system's database. The administrator can view the student's attendance records. The students use the fingerprint scanner to input attendance records. The biometric device then verifies the fingerprint then save it to the system database. After verification, the system sends an SMS message to the mobile device of the parent or guardian for notification through SMS broadband.

\subsection{Methods}

The descriptive method of research is used in this study, allowing the proponents to assess and record the details of the operation. The descriptive method is preferred for the reason that the information gathered in this method is reasonably quantifiable. The attitudes, behaviors, and insights that are held concerning a given subject is revealed and adequately measured. This method is used to complete the final structure of the system. Quantitative forms of research, such as questionnaires and personal interviews, are done under this phase to obtain additional information for the development. The researchers used System Development Life Cycle (SDLC), Rapid Application Development (RAD) [29], as shown in Figure 3 to conduct a preliminary investigation, initiation or inception, analysis of the cost and requirements, definition of the system method used in designing, testing, implementing and maintaining.

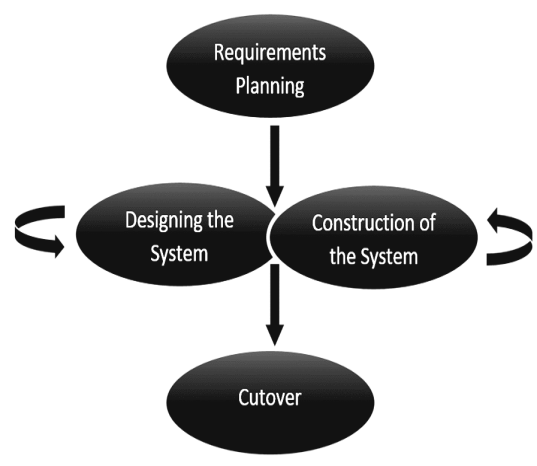

Figure 3: Illustration of Rapid Application Development Model (RAD)

There are four phases involved in system development. These are the requirement planning phase in which authors have determined the requirements in creating the system. Secondly is the designing phase in which is used to create the appropriate design of the system. Thirdly, the construction phase in which is created for the functionalities of the system. Lastly, the cut-over phase or the final phase to handle data, convert from the current process to the new system, full testing, and user training.

\section{Phase I. Conceptualization of the System Software}

At first, preparing a plan and selecting the individuals who have direct involvement in the objective of the study. The researchers assessed the over-all scope of the problem. The researchers thought of a system that could solve the problems in monitoring the attendance of the students thru the fingerprint scanner, and that would notify parents about the attendance of their child thru SMS. The researchers have started gathering information and ideas about the project. The researchers have also gathered information from the internet, libraries, and documentation from past projects which were related to the study. After all, data is collected, the researchers started to work with the project.

\section{Phase II. Designing of the System Software}

After understanding the process, the researchers reviewed all data and information for the construction of the project. The researchers focused on the basics and operation flow of the project. Contemplating the flow of the system is the first thing that was accomplished to determine the connections of all the devices. After that, the researchers thought of a design that would make the system more presentable and appealing in the eye of the user. After in-depth research, the researchers determined what hardware was used in constructing the project.

Phase III. Implementation and testing of the System

\section{Software}

The system underwent testing to make sure that it meets the user's needs, to eliminate errors during the program cycle, and to determine the system's reliability and feasibility. Before implementing the system, different types of testing were performed during the construction phase in determining the risk ad possible solutions for the validation of the application's accuracy and completeness in the performance of the functions as designed. The system underwent Application Testing, Alpha Testing, Beta Testing, Performance Testing, and Acceptance Testing. Application Testing was performed in three ways. First is the unit testing to ensure that the system operates with reliability and accuracy, and secondly, operating procedures are tested to determine if they are fit for use when all modules are complete. Integration testing was also performed to verify that the modules operate correctly as a system. After unit and integration testing was completed, the system testing follows to ensure that all hardware and software components are compatible and working together as a whole. System testing comes next to perform and simulate daily workloads and to make sure that the processing speed and accuracy meets the specifications. Alpha testing was performed to evaluate whether the functionalities of the system are working correctly. Beta Testing was also used to gather new ideas, suggestions, and comments from the clients and for them to criticize the system for improvement. Unit Testing was used to test methods by which individual units of source code to determine whether they are fit for use. Acceptance Testing was performed as the final stage of the testing phase. This is designed to ensure that the user of the system performs what he or she is supposed and expected to do and accomplish.

\subsection{Software tools}

The developers used the following tools in developing the said system. 
Gantt chart. It was served as a planning tool to provide a schedule of planned activities throughout the study until the implementation of the LAN-based system.

Hierarchical Input Process Output (HIPO). It was used to view the structure of the system plan or the system structure in a logical structure and conceptual framework.

Flowchart. It was used by the researchers to show the graphical representation and the flow or sequence in the manual and online system.

Entity Relationship Diagram (ERD). It was used in designing databases since it is a data model that provides basic graphical symbols to show the organization's relationships between data and confirmed the involvement of entities that are being utilized. In this study, the ERD was used to represent the overall logical structure of the database. Storyboard. It was used to understand and illustrate the actual process of the system in a manual and computerized system.

\section{Programming}

researchers used programming to create a Windows Forms Application. The primary programming language that was used is VB.NET, which is common in developing Windows Forms Applications. This tool features a secure coding for Windows-Based design. On the other part of the system comes storing of information is the MySQL Workbench for itself were optimized for saving data. With the use of this database, data is stored and retrieved, where it automatically provides the record if needed. Figure $4 \mathrm{a}$ shows the student's process flow using the system. The students tap their fingerprint on the fingerprint scanner, and the biometric device verifies the fingerprint. If verification is successful, the system sends an SMS message to the mobile device of the parent or guardian for notification through SMS broadband. If not verified, it goes back to the first process.

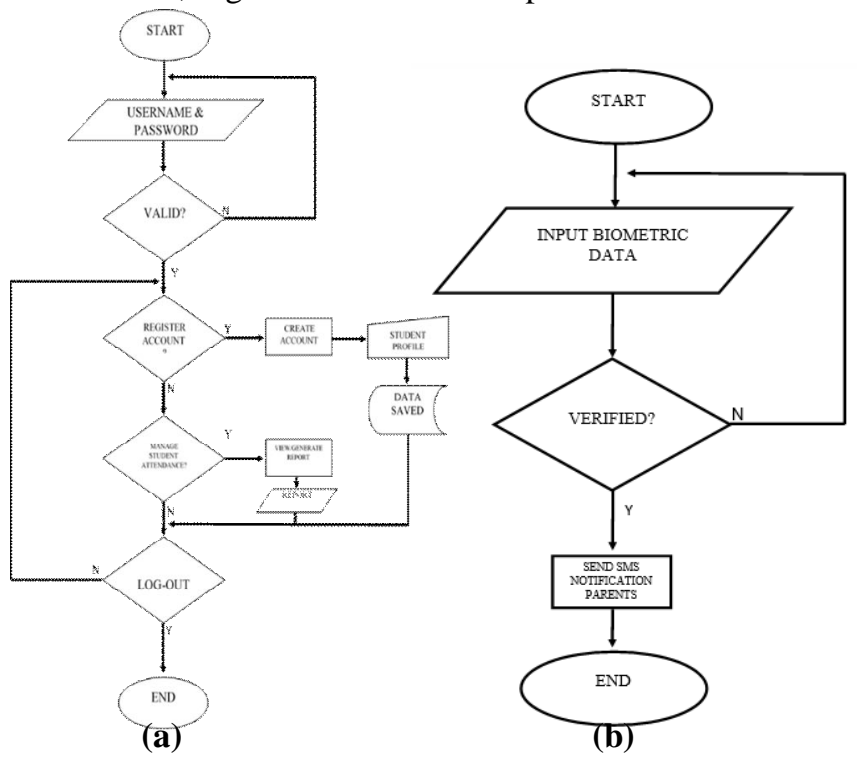

Figure 4: Flowcharts utilized. (a) Flowchart of the system for the student; (b) Flowchart of the system for system administrator

\section{Flowchart of the system for system administrator}

Figure $4 \mathrm{~b}$ shows the process flow of an administrator using the system. The Figure shows that the system administrator needs to log-in to the system. If the administrator account is valid, the administrator can either register account, manage the student's record, or log-out from the system. If the account is not valid in the system, it goes back to the first process. If the administrator chooses to register the account, the student's information is registered and stored in the system's database. If the administrator chooses to manage student attendance, the administrator can view or generate the student's attendance record. If the administrator chooses to log-out the account, it will be logged-out, then proceeds to the first process.

\subsection{Software Specifications}

The Paperless Smart Classroom Attendance System using Fingerprint Biometric with SMS through Rapid Application Development Tool was developed under VB.NET. The user must have a Windows Operating System to use the system and a desktop for the system admin.

Table 1 shows the software that has been used in the development of the system project. It was shown in the table what is the minimum required software along with its recommended software.

Table 1: Software Specifications in developing the Windows-Based Application

\begin{tabular}{|c|c|c|}
\hline Category & Used & $\begin{array}{c}\text { Minimum } \\
\text { Requirements }\end{array}$ \\
\hline Developer & Visual Studio 2017 & Visual Studio 2010 \\
\hline Server & $\begin{array}{c}\text { MySQL } \\
\text { Workbench 6.3 }\end{array}$ & MySQL Workbench 6.3 \\
\hline User & $\begin{array}{c}\text { Windows 8 } \\
\text { Operating System }\end{array}$ & $\begin{array}{c}\text { Windows 7 Operating } \\
\text { System }\end{array}$ \\
\hline
\end{tabular}

\subsection{Hardware Specifications}

The hardware specifications are listed in table 2, stating the minimum and recommended requirements in using the system. It also indicates the hardware that was used in the development of the system. 
Table 2: Hardware Specifications requirements in developing the system

\begin{tabular}{|c|c|c|}
\hline Category & Hardware & $\begin{array}{c}\text { Minimum } \\
\text { Requirements }\end{array}$ \\
\hline \multirow[t]{3}{*}{ Server } & Laptop & $\begin{array}{c}3^{\text {rd }} \text { Generation Intel } \\
\text { Core i5 - 3300 } \\
\text { 3.00GHz Intel HD } \\
\text { Graphics Family } \\
\text { 1760MB Memory 8GB } \\
\text { DDR3 - Storage } \\
\text { 500GB 15.5" HD } \\
\text { Display, Windows 7 }\end{array}$ \\
\hline & Biometric Reader & ZK4500 \\
\hline & Broadband Stick & $\begin{array}{c}\text { Huawei Mobile } \\
\text { Connect }\end{array}$ \\
\hline \multirow[t]{3}{*}{ Client } & Laptop & $\begin{array}{c}3^{\text {rd }} \text { Generation Intel } \\
\text { Core i5 - 3300 } \\
\text { 3.00GHz Intel HD } \\
\text { Graphics Family } \\
\text { 1760MB Memory 8GB } \\
\text { DDR3 - Storage } \\
\text { 500GB 15.5" HD } \\
\text { Display, Windows 7 }\end{array}$ \\
\hline & Biometric Reader & ZK4500 \\
\hline & Broadband Stick & $\begin{array}{c}\text { Huawei Mobile } \\
\text { Connect }\end{array}$ \\
\hline
\end{tabular}

\subsection{System Architecture}

Figure 5 shows the system architecture of the study. It is the process flow of the system from logging-in into the system by the system administrator and registration of student accounts. It also shows the process flow of the student's operation in the system. The system administrator needs to log-in to the system to register a student's account, and the accounts The registered are stored in the system's database. The administrator can view student's attendance records and that the students use the fingerprint scanner to input attendance records. The biometric device verifies the fingerprint then save it to the system database. After verification, the system sends an SMS message to the mobile device for notification through SMS broadband.

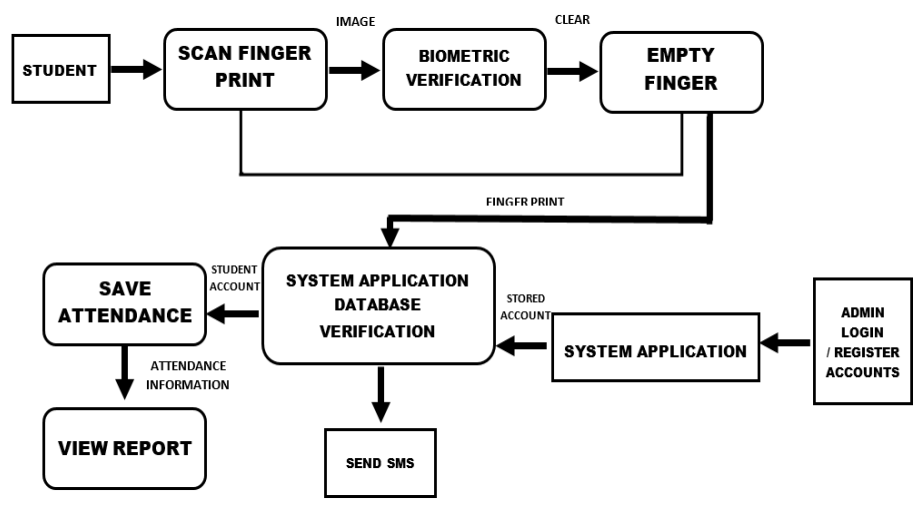

Figure 5: System architecture used in the system

\section{RESULTS AND DISCUSSION}

As described previously, several tests have conducted to validate the functionalities of the system. The tests were performed, and results were shown, as stated in the next discussions.

\subsection{Hardware components testing}

Table 3 discusses the testing of several hardware components. These tests were performed to obtain the objectives of the system.

Table 3: Hardware components testing conducted

\begin{tabular}{|c|c|c|c|}
\hline \multicolumn{4}{|c|}{ Hardware Components } \\
\hline $\begin{array}{l}\text { Hardware } \\
\text { Components }\end{array}$ & $\begin{array}{c}\text { Usage Trial } \\
\# 1\end{array}$ & $\begin{array}{c}\text { Usage Trial } \\
\# 2\end{array}$ & Remarks \\
\hline Biometric & $\begin{array}{c}\text { The } \\
\text { biometric } \\
\text { needs driver } \\
\text { to be } \\
\text { installed in } \\
\text { order to be } \\
\text { used. }\end{array}$ & $\begin{array}{l}\text { The driver is } \\
\text { installed and } \\
\text { in working } \\
\text { condition }\end{array}$ & $\begin{array}{l}\text { The biometric is } \\
\text { working as long } \\
\text { as it is connected } \\
\text { to the computer. }\end{array}$ \\
\hline $\begin{array}{l}\text { Broadband } \\
\text { Stick }\end{array}$ & $\begin{array}{c}\text { The } \\
\text { broadband } \\
\text { stick needs a } \\
\text { driver to be } \\
\text { installed } \\
\text { first. }\end{array}$ & $\begin{array}{c}\text { The } \\
\text { broadband } \\
\text { stick needs } \\
\text { SIMCARD to } \\
\text { be used with } \\
\text { SMS. }\end{array}$ & $\begin{array}{l}\text { The broadband } \\
\text { stick was used in } \\
\text { order to send } \\
\text { SMS. }\end{array}$ \\
\hline Webcam & $\begin{array}{l}\text { The webcam } \\
\text { needs a } \\
\text { driver in } \\
\text { order to be } \\
\text { read by the } \\
\text { computer. }\end{array}$ & $\begin{array}{l}\text { The } \\
\text { computer } \\
\text { recognizes } \\
\text { the webcam } \\
\text { attached. }\end{array}$ & $\begin{array}{l}\text { The webcam was } \\
\text { used to take } \\
\text { pictures of } \\
\text { students during } \\
\text { registration. }\end{array}$ \\
\hline $\begin{array}{l}\text { Personal } \\
\text { Computer }\end{array}$ & $\begin{array}{l}\text { The system } \\
\text { needs to be } \\
\text { factory reset } \\
\text { to remove } \\
\text { un-necessary } \\
\text { programs } \\
\text { and be able } \\
\text { to refresh the } \\
\text { system. }\end{array}$ & $\begin{array}{c}\text { It is in } \\
\text { working } \\
\text { condition. }\end{array}$ & $\begin{array}{l}\text { Resetting the } \\
\text { system gives } \\
\text { faster speeds. }\end{array}$ \\
\hline
\end{tabular}

\subsection{Software components testing}

Testing the functionalities of the software sets were also conducted. This is presented in Table 4.

\subsection{System components testing}

Table 5 was also formulated to validate the functionalities of each system component included in the system.

\subsection{Integration testing and Acceptance testing}

Table 6 is the result of the integration testing, while Table 7 is about acceptance testing. In these tests it indicates that the obtained result is desirable as to the objectives of the study. 
Table 4: Software sets testing done

\begin{tabular}{|c|c|c|c|}
\hline Software & $\begin{array}{c}\text { Usage Trial } \\
\# 1\end{array}$ & $\begin{array}{c}\text { Usage } \\
\text { Trial \#2 }\end{array}$ & Remarks \\
\hline $\begin{array}{c}\text { VB.NET } \\
\text { Programming } \\
\text { Language }\end{array}$ & $\begin{array}{c}\text { Installed } \\
\text { Successfully. }\end{array}$ & $\begin{array}{c}\text { It is in } \\
\text { working } \\
\text { condition }\end{array}$ & $\begin{array}{l}\text { Visual Studio } \\
2010 \text { or higher } \\
\text { is required. }\end{array}$ \\
\hline MySQL 5.7 & $\begin{array}{c}\text { Installed } \\
\text { Successfully. }\end{array}$ & $\begin{array}{c}\text { It is in } \\
\text { working } \\
\text { condition } \\
\end{array}$ & $\begin{array}{c}\text {.NET } \\
\text { Framework } 4.5 \\
\text { and Visual } \\
\text { C++ } \\
\text { Redistributable } \\
\text { For Visual } \\
\text { Studio }\end{array}$ \\
\hline $\begin{array}{c}\text { MySQL } \\
\text { Workbench } \\
\text { Community } \\
\text { Edition }\end{array}$ & $\begin{array}{c}\text { Installed } \\
\text { Successfully }\end{array}$ & $\begin{array}{c}\text { It is in } \\
\text { working } \\
\text { condition } \\
\end{array}$ & $\begin{array}{c}\text {.NET } \\
\text { Framework } 4.5 \\
\text { and Visual } \\
\text { C++ } \\
\text { Redistributable } \\
\text { For Visual } \\
\text { Studio 2015 is } \\
\text { required to } \\
\text { fully function. }\end{array}$ \\
\hline $\begin{array}{c}\text { Visual Studio } \\
2017 \\
\text { Community } \\
\text { Edition }\end{array}$ & $\begin{array}{c}\text { Installed } \\
\text { Successfully }\end{array}$ & $\begin{array}{c}\text { It is in } \\
\text { working } \\
\text { condition }\end{array}$ & $\begin{array}{c}\text {.NET } \\
\text { Framework } 4.5 \\
\text { is required, } \\
\text {.NET } \\
\text { Framework } \\
4.6 .1 \text { was } \\
\text { installed } \\
\text { during setup. }\end{array}$ \\
\hline $\begin{array}{l}\text { ZDK Finger } \\
\text { Driver / SDK }\end{array}$ & $\begin{array}{c}\text { Installed } \\
\text { Successfully }\end{array}$ & $\begin{array}{c}\text { It is in } \\
\text { working } \\
\text { condition }\end{array}$ & $\begin{array}{l}\text { ZDK SDK } \\
\text { Driver is } \\
\text { required to be } \\
\text { integrated into } \\
\text { the system. }\end{array}$ \\
\hline $\begin{array}{l}\text { Huawei } \\
\text { Mobile } \\
\text { Connect } \\
\text { Driver }\end{array}$ & $\begin{array}{c}\text { Installed } \\
\text { Successfully }\end{array}$ & $\begin{array}{c}\text { It is in } \\
\text { working } \\
\text { condition } \\
\text {. }\end{array}$ & $\begin{array}{l}\text { Huawei Mobile } \\
\text { Connect } \\
\text { Driver is } \\
\text { needed to be } \\
\text { able to } \\
\text { communicate } \\
\text { with the } \\
\text { PORT/COM } \\
\text { given to the } \\
\text { device. }\end{array}$ \\
\hline $\begin{array}{l}\text { Webcam } \\
\text { Driver }\end{array}$ & $\begin{array}{c}\text { Installed } \\
\text { Successfully. }\end{array}$ & $\begin{array}{c}\text { It is in } \\
\text { working } \\
\text { condition }\end{array}$ & $\begin{array}{l}\text { Webcam } \\
\text { Driver is } \\
\text { needed to } \\
\text { function fully. }\end{array}$ \\
\hline
\end{tabular}

Table 5: System components testing conducted

\begin{tabular}{|c|c|c|c|}
\hline $\begin{array}{c}\text { System } \\
\text { components }\end{array}$ & Usage Trial \#1 & $\begin{array}{c}\text { Usage } \\
\text { Trial \#2 }\end{array}$ & Remarks \\
\hline $\begin{array}{c}\text { Check } \\
\text { Attendance }\end{array}$ & $\begin{array}{l}\text { Communicatio } \\
n \text { of the } \\
\text { biometric } \\
\text { device and the } \\
\text { system also } \\
\text { tests if the SMS } \\
\text { is sending. }\end{array}$ & $\begin{array}{l}\text { Fingerprint } \\
\text { template } \\
\text { read from } \\
\text { the } \\
\text { database, } \\
\text { SMS is } \\
\text { working } \\
\text { properly. }\end{array}$ & $\begin{array}{l}\text { Configured } \\
\text { the } \\
\text { connection } \\
\text { of the } \\
\text { system to } \\
\text { the database } \\
\text { then } \\
\text { programme } \\
\text { d the codes } \\
\text { to be able to } \\
\text { identify the } \\
\text { fingerprint } \\
\text { template } \\
\text { from the } \\
\text { database. }\end{array}$ \\
\hline Add Students & $\begin{array}{l}\text { Communicate } \\
\text { with the } \\
\text { database thru } \\
\text { programming } \\
\text { to be able to add } \\
\text { records on the } \\
\text { database. }\end{array}$ & $\begin{array}{c}\text { It is in } \\
\text { working } \\
\text { condition }\end{array}$ & $\begin{array}{l}\text { The } \\
\text { function is } \\
\text { working } \\
\text { properly }\end{array}$ \\
\hline View Reports & $\begin{array}{l}\text { Communicate } \\
\text { with the } \\
\text { database thru } \\
\text { programming } \\
\text { to fetch needed } \\
\text { data from the } \\
\text { database to be } \\
\text { displayed on a } \\
\text { data grid. }\end{array}$ & $\begin{array}{l}\text { Sorting of } \\
\text { records } \\
\text { according } \\
\text { to user } \\
\text { preferences. }\end{array}$ & $\begin{array}{c}\text { The } \\
\text { function is } \\
\text { working } \\
\text { properly }\end{array}$ \\
\hline Add Accounts & $\begin{array}{l}\text { Create new user } \\
\text { log-ins to be } \\
\text { able to use the } \\
\text { system. }\end{array}$ & $\begin{array}{c}\text { Set } \\
\text { biometric as } \\
\text { a back-up in } \\
\text { case they } \\
\text { forgot their } \\
\text { username } \\
\text { or } \\
\text { password. }\end{array}$ & $\begin{array}{l}\text { User log-ins } \\
\text { can also use } \\
\text { their } \\
\text { biometrics } \\
\text { to log-in to } \\
\text { the system } \\
\text { as long as } \\
\text { they are } \\
\text { enrolled in } \\
\text { the system. }\end{array}$ \\
\hline $\begin{array}{l}\text { Manage } \\
\text { Database }\end{array}$ & $\begin{array}{l}\text { The system is } \\
\text { able to Export a } \\
\text { database for } \\
\text { back-up } \\
\text { purposes. }\end{array}$ & $\begin{array}{l}\text { The system } \\
\text { is able to } \\
\text { Import } \\
\text { from a } \\
\text { recent } \\
\text { back-up of } \\
\text { the } \\
\text { database. }\end{array}$ & $\begin{array}{l}\text { The } \\
\text { function is } \\
\text { working } \\
\text { properly }\end{array}$ \\
\hline
\end{tabular}


Table 6: Integration testing conducted

\begin{tabular}{|c|c|c|c|}
\hline Functionality & $\begin{array}{c}\text { Usage Trial } \\
\# 1\end{array}$ & $\begin{array}{c}\text { Usage } \\
\text { Trial \#2 }\end{array}$ & Remarks \\
\hline $\begin{array}{l}\text { Connection of } \\
\text { the System to } \\
\text { the Database }\end{array}$ & $\begin{array}{l}\text { A firewall is } \\
\text { blocking } \\
\text { outbound } \\
\text { and inbound } \\
\text { connection. }\end{array}$ & $\begin{array}{l}\text { Exempted } \\
\text { in the } \\
\text { firewall. }\end{array}$ & $\begin{array}{l}\text { Configured } \\
\text { exemption in } \\
\text { the firewall in } \\
\text { order to } \\
\text { communicate } \\
\text { with the } \\
\text { database. }\end{array}$ \\
\hline $\begin{array}{l}\text { Connection of } \\
\text { biometric } \\
\text { device to the } \\
\text { system }\end{array}$ & $\begin{array}{l}\text { Import the } \\
\text { SDK to the } \\
\text { system } \\
\text { using the } \\
\text { pre-installe } \\
\text { d driver. }\end{array}$ & $\begin{array}{l}\text { Biometric } \\
\text { device } \\
\text { coded to } \\
\text { connect to } \\
\text { the system. }\end{array}$ & $\begin{array}{l}\text { Coding the } \\
\text { biometric to the } \\
\text { device lets it } \\
\text { communicate } \\
\text { with the system. }\end{array}$ \\
\hline $\begin{array}{c}\text { Connection of } \\
\text { broadband stick } \\
\text { to the system }\end{array}$ & $\begin{array}{l}\text { Identify the } \\
\text { Serial Port } \\
\text { number } \\
\text { used by the } \\
\text { device. }\end{array}$ & $\begin{array}{l}\text { Insert the } \\
\text { Serial Port } \\
\text { number to } \\
\text { the system. }\end{array}$ & $\begin{array}{c}\text { Communicatio } \\
\mathrm{n} \text { is continuous } \\
\text { as long as it is } \\
\text { not } \\
\text { disconnected } \\
\text { physically. }\end{array}$ \\
\hline
\end{tabular}

Table 7: Acceptance testing conducted

\begin{tabular}{|c|c|c|c|}
\hline Functionality & Usage Trial \#1 & Usage Trial \#2 & Remarks \\
\hline $\begin{array}{l}\text { Connection of } \\
\text { the System to } \\
\text { the Database }\end{array}$ & $\begin{array}{l}\text { Connections } \\
\text { can be made. }\end{array}$ & $\begin{array}{l}\text { Connections } \\
\text { can be made. }\end{array}$ & None \\
\hline $\begin{array}{c}\text { Communicatio } \\
\mathrm{n} \text { of the System } \\
\text { and the } \\
\text { Database }\end{array}$ & $\begin{array}{l}\text { Inbound and } \\
\text { Outbound } \\
\text { communication } \\
\text { s can be made. }\end{array}$ & $\begin{array}{l}\text { Communicatio } \\
\mathrm{n} \text { can be made. }\end{array}$ & None \\
\hline $\begin{array}{l}\text { Send SMS to } \\
\text { Parents }\end{array}$ & $\begin{array}{l}\text { Outbound } \\
\text { Messages can be } \\
\text { sent thru the } \\
\text { system upon } \\
\text { registering and } \\
\text { upon checking } \\
\text { of attendance. }\end{array}$ & $\begin{array}{c}\text { SMS sent } \\
\text { successfully. }\end{array}$ & $\begin{array}{l}\text { The } \\
\text { SIMCARD } \\
\text { should have } \\
\text { nough load } \\
\text { balance in } \\
\text { order to } \\
\text { send SMS. }\end{array}$ \\
\hline $\begin{array}{l}\text { Checking of } \\
\text { attendance thru } \\
\text { Biometric }\end{array}$ & $\begin{array}{l}\text { Checking of } \\
\text { attendance can } \\
\text { be done thru } \\
\text { fingerprint data. }\end{array}$ & $\begin{array}{c}\text { It is } \\
\text { working } \\
\text { properly. }\end{array}$ & $\begin{array}{l}\text { The } \\
\text { fingerprin } \\
\text { t Reader } \\
\text { surface } \\
\text { must be } \\
\text { cleaned to } \\
\text { avoid } \\
\text { errors. }\end{array}$ \\
\hline $\begin{array}{c}\text { Import/Export } \\
\text { Database }\end{array}$ & $\begin{array}{l}\text { Importing and } \\
\text { Exporting } \\
\text { Database is } \\
\text { working } \\
\text { properly. }\end{array}$ & $\begin{array}{l}\text { It is working } \\
\text { properly. }\end{array}$ & None \\
\hline $\begin{array}{l}\text { Import Student } \\
\text { Record from } \\
\text {.xls / .xlsx file } \\
\text { extension }\end{array}$ & $\begin{array}{l}\text { Import students } \\
\text { if the excel } \\
\text { matched the } \\
\text { table rows in the } \\
\text { database. }\end{array}$ & $\begin{array}{l}\text { It is working } \\
\text { properly. }\end{array}$ & None \\
\hline
\end{tabular}

\section{Administrator's account registration test}

The registration test was done for accounts of administrators through table 8 . The table showed sample 10 system administrators' accounts, which was successfully registered in the system's database. The ACCOUNTID column refers to the database accountid per record within the database. The LASTNAME, FIRSTNAME, MI column is the personal information of the account holder. The PASSWORD column is about the registered credentials to be used by the system administrators in login-in to the system. The CONFIRMPASSWORD column is the validation that the entered password and the confirmation password match. The table summarizes that the registration of the administrator's accounts and validation was successful.

Table 8: Administrator's account registration test data

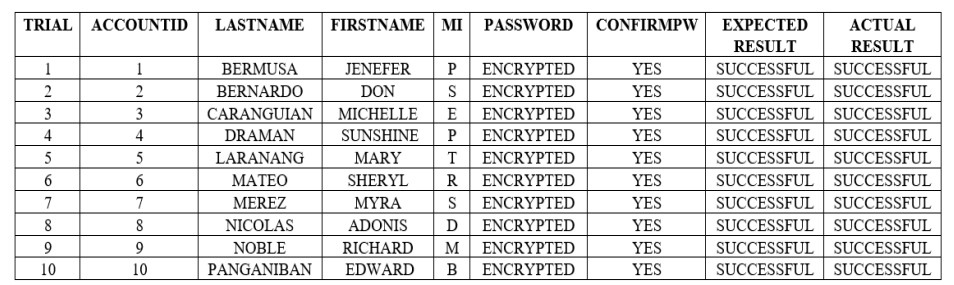

\subsection{Fingerprint biometrics registration test and SMS} notification test

For registration of biometrics and SMS notification testing, Table 9 shows sample 10 instances were successfully registered in the biometrics, and sample 10 instances had successfully sent SMS notification. The TRIAL column refers to the number of samples conducted. The USN column is the usn of students per record. The LASTNAME, FIRSTNAME, MI column is about the personal information of the student. Lastly, the column BIOMETRIX CODE HEX and IMAGE CODE HEX columns refer to the code registered with respect per record. Based on the table, actual results showed that the system works properly based on expected outputs.

Table 9: Fingerprint biometrics registration test and SMS notification test data

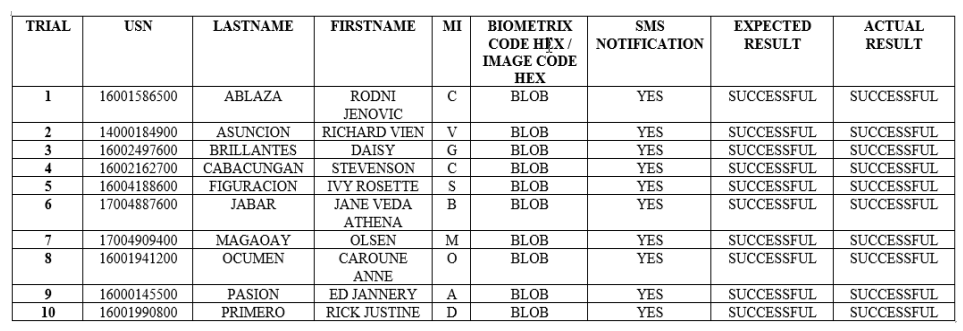




\subsection{Fingerprint biometrics in-out test and SMS notification test}

Table 10 is about the testing of student attendance through the biometric device. It shows that the attendance system had obtained the expected functions. The TRIAL column shows the number of trials conducted. The USN column is the USN number of the students recorded in the database. The BIOMETRIX CODE HEX column is about the fingerprint biometrics code with respect to per student record. The FINGERPRINT VERIFIED IN column means that the scanned fingerprint was successfully verified when the student entered the classroom. The SMS NOTIFIED IN column means that the SMS notification was successfully sent when the student entered the classroom for the time in attendance. The FINGERPRINT VERIFIED OUT column provides data if the fingerprint was successfully verified when the student exit the classroom. The SMS NOTIFIED OUT column specifies if the SMS notification was successfully sent when the student exited the classroom for time out attendance. Hence, based on the table shown, the fingerprint biometrics in-out test and SMS notification test had obtained the expected results.

Table 10: Fingerprint biometrics in-out test and SMS notification test data

\begin{tabular}{|c|c|c|c|c|c|c|}
\hline TRIAL & USN & $\begin{array}{c}\text { BIOMETRIX } \\
\text { CODE HEX }\end{array}$ & $\begin{array}{c}\text { FINGERPRINT } \\
\text { VERIFIED IN }\end{array}$ & $\begin{array}{c}\text { SMS } \\
\text { NOTIFIED } \\
\text { IN }\end{array}$ & $\begin{array}{c}\text { FINGERPRINT } \\
\text { VERIFIED } \\
\text { OUT }\end{array}$ & $\begin{array}{c}\text { SMS } \\
\text { NOTIFIED } \\
\text { OUT }\end{array}$ \\
\hline 1 & 16001586500 & BLOB & YES & YES & YES & YES \\
\hline 2 & 14000184900 & BLOB & YES & YES & YES & YES \\
\hline 3 & 16002497600 & BLOB & YES & YES & YES & YES \\
\hline 4 & 16002162700 & BLOB & YES & YES & YES & YES \\
\hline 5 & 16004188600 & BLOB & YES & YES & YES & YES \\
\hline 6 & 17004887600 & BLOB & YES & YES & YES & YES \\
\hline 7 & 17004909400 & BLOB & YES & YES & YES & YES \\
\hline 8 & 16001941200 & BLOB & YES & YES & YES & YES \\
\hline 9 & 16000145500 & BLOB & YES & YES & YES & YES \\
\hline 10 & 16001990800 & BLOB & YES & YES & YES & YES \\
\hline
\end{tabular}

\subsection{Software Development}

Figure 6 is the actual home screen of the system administrator. The home screen displays several functions like the manage account function wherein this manages all the account stored in the database. The Add Students' function allows the administrator to register and manage students' records to the database. The View Report Function provides the administrator to view the students' records per day/week/monthly or through date range. The Manage database function serves the administrator to back-up and restores the system database. The SMS Setting function is used by the administrator to assign the correct port designation for the SMS notification. The About function displays the developer of the system. Finally, the Log-out function is for the administrator to log-out from the system.

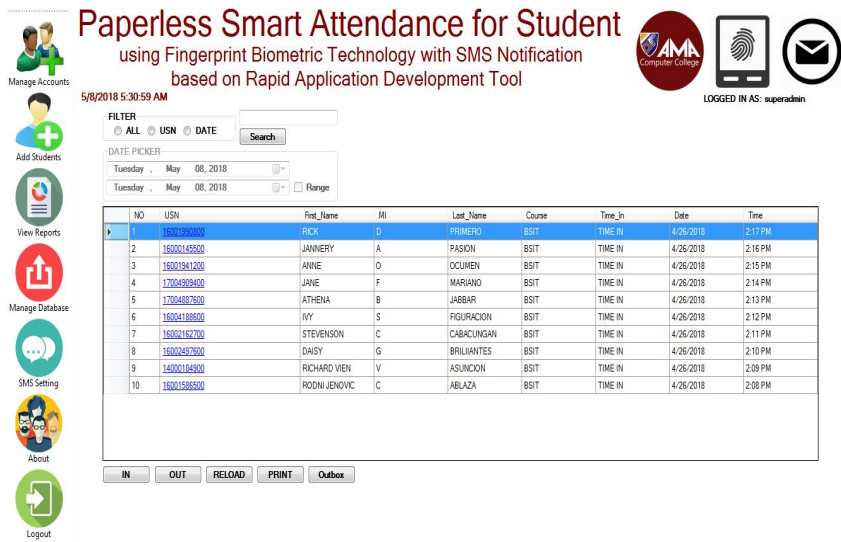

Figure.6: Administrator home screen of the system

\section{The final prototype of the system}

Figure 7 is the final prototype of the study. The Figure shows the system hardware components. The webcam is used to capture images for student account registration. The monitor is used for managing and viewing records. The system is installed on a desktop computer. The fingerprint biometric is used for the time-in and time-out of the student. A broadband stick is detachable that is used to transmit SMS notification to the mobile device of the parents.

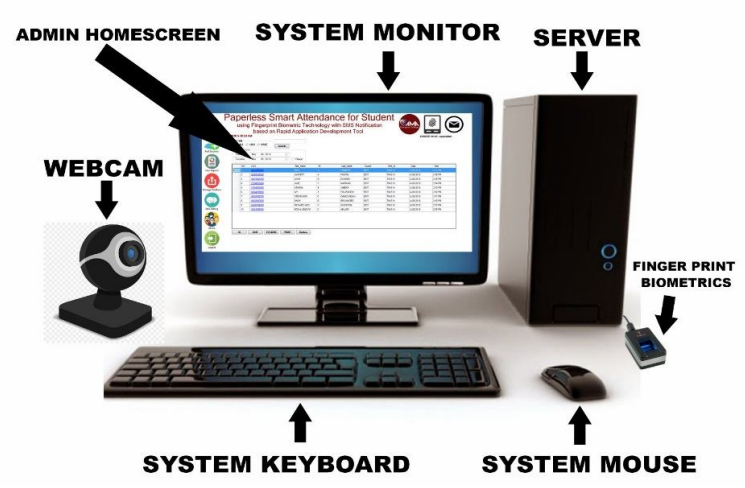

Figure 7: The final prototype of the system

\subsection{Software Evaluation}

Questionnaires were distributed to the respondents to evaluate the functionality, usability, and reliability of the "Paperless Smart Classroom Attendance System using Fingerprint Biometric with SMS through Rapid Application Development Tool." The questionnaire was based on the international standard for the evaluation of software quality ISO/IEC 25010:2011.

The total number of respondents was 250 , which comprises of students, parents, and employees of the AMA Santiago Campus. The data was gathered last July 2017. Table 11 shows the mean perception of the respondents on the functionality of the study. The result revealed that the majority of the respondents strongly agree on the specified functionalities of the design project with an overall weighted mean of 4.67. Table 12 shows the mean perception of the respondents regarding their usability. Results revealed an 
overall weighted mean of 4.76 , which implies that the respondents strongly agree on the usability of the design project. Finally, Table 13 presents the mean perception of the respondents when it comes to its reliability. The overall weighted mean of 4.65 indicates that the respondents strongly agree on the reliability of the system.

Table 11: Respondents' rating on the functionality of the system tabulated result

\begin{tabular}{|c|c|c|}
\hline Criteria & $\begin{array}{c}\text { Weighte } \\
\text { d Mean }\end{array}$ & $\begin{array}{c}\text { Descriptive } \\
\text { Equivalent }\end{array}$ \\
\hline $\begin{array}{c}\text { The system displays confirmation } \\
\text { when successfully registered a new } \\
\text { account. }\end{array}$ & 4.65 & $\begin{array}{c}\text { Strongly } \\
\text { Agree }\end{array}$ \\
\hline $\begin{array}{c}\text { The system displays error notification } \\
\text { when registration is not successful. }\end{array}$ & 4.62 & $\begin{array}{c}\text { Strongly } \\
\text { Agree }\end{array}$ \\
\hline $\begin{array}{c}\text { The system sends SMS notification } \\
\text { when the student logs-in into the } \\
\text { system. }\end{array}$ & 4.77 & $\begin{array}{c}\text { Strongly } \\
\text { Agree }\end{array}$ \\
\hline $\begin{array}{c}\text { The system sends SMS notification } \\
\text { when the student log-out from the } \\
\text { system. }\end{array}$ & 4.6 & $\begin{array}{c}\text { Strongly } \\
\text { Agree }\end{array}$ \\
\hline $\begin{array}{c}\text { The system displays the account } \\
\text { information of the students when } \\
\text { he/she log-in and log-out in the } \\
\text { system. }\end{array}$ & 4.73 & $\begin{array}{c}\text { Strongly } \\
\text { Agree }\end{array}$ \\
\hline Overall Weighted Mean & 4.67 & $\begin{array}{c}\text { Strongly } \\
\text { Agree }\end{array}$ \\
\hline
\end{tabular}

Table 12: Respondents' rating on the usability of the system tabulated result

\begin{tabular}{|c|c|c|}
\hline Criteria & $\begin{array}{l}\text { Weighte } \\
\text { d Mean }\end{array}$ & $\begin{array}{c}\text { Descriptiv } \\
\text { e } \\
\text { Equivalent }\end{array}$ \\
\hline $\begin{array}{c}\text { The system is easy to use and } \\
\text { understand. }\end{array}$ & 4.9 & $\begin{array}{l}\text { Strongly } \\
\text { Agree }\end{array}$ \\
\hline The system is easy to operate. & 4.88 & $\begin{array}{l}\text { Strongly } \\
\text { Agree }\end{array}$ \\
\hline $\begin{array}{l}\text { The design project is easy to } \\
\text { remember system procedure. }\end{array}$ & 4.73 & $\begin{array}{l}\text { Strongly } \\
\text { Agree }\end{array}$ \\
\hline $\begin{array}{c}\text { The system is suited to its intended } \\
\text { users. }\end{array}$ & 4.77 & $\begin{array}{l}\text { Strongly } \\
\text { Agree }\end{array}$ \\
\hline $\begin{array}{l}\text { The system has the ability to send an } \\
\text { SMS notification to the student's } \\
\text { guardian. }\end{array}$ & 4.5 & $\begin{array}{l}\text { Strongly } \\
\text { Agree }\end{array}$ \\
\hline Overall Weighted Mean & 4.76 & $\begin{array}{l}\text { Strongly } \\
\text { Agree }\end{array}$ \\
\hline
\end{tabular}

Table 13: Respondents' rating on the reliability of the system tabulated result

\begin{tabular}{|c|c|c|}
\hline Criteria & $\begin{array}{c}\text { Weighted } \\
\text { Mean }\end{array}$ & $\begin{array}{c}\text { Descriptive } \\
\text { Equivalent }\end{array}$ \\
\hline $\begin{array}{c}\text { The system continues to } \\
\text { operate when it encountered } \\
\text { an error. }\end{array}$ & 4.69 & $\begin{array}{c}\text { Strongly } \\
\text { Agree }\end{array}$ \\
\hline $\begin{array}{c}\text { The system operations can be } \\
\text { restored quickly when a }\end{array}$ & 4.62 & $\begin{array}{c}\text { Strongly } \\
\text { Agree }\end{array}$ \\
\hline
\end{tabular}

\begin{tabular}{|c|c|c|}
\hline failure occurred. & & Atrongly \\
Agree \\
$\begin{array}{c}\text { The system maintains the } \\
\text { integrity of records upon } \\
\text { recovery. }\end{array}$ & 4.62 & $\begin{array}{c}\text { Strongly } \\
\text { Agree }\end{array}$ \\
\hline $\begin{array}{c}\text { The system sends SMS } \\
\text { notification reliably. }\end{array}$ & 4.69 & $\begin{array}{c}\text { Strongly } \\
\text { Agree }\end{array}$ \\
\hline $\begin{array}{c}\text { The system provides back-up } \\
\text { and recovery of records when } \\
\text { disturbance encountered. }\end{array}$ & 4.62 & $\begin{array}{c}\text { Strongly } \\
\text { Agree }\end{array}$ \\
\hline Overall Weighted Mean & 4.65 & \\
\hline
\end{tabular}

\section{CONCLUSION}

The "Paperless Smart Classroom Attendance System using Fingerprint Biometric with SMS through Rapid Application Development Tool" is a system developed to have an automated and real-time student attendance monitoring with real-time notification to parents thru SMS as well as to help environment preserve papers which are used in every attendance taking. Paperless processing makes the system environmentally friendly. The attendance of students can be verified through mobile phones of the parents or guardians as well as the delinquent students can be viewed through the system by the faculty and staff of the school.

The research design used in the system were the descriptive method and the System Development Life Cycle, particularly Rapid Application Development (RAD). The interview, library, questionnaire, observation, and internet research were used as instruments in data gathering. Stages of development of the system were conceptualized, together with several methods that were helpful to come up with a reliable system. The Gantt Chart, Entity Relationship Diagram (ERD), flowcharts, storyboard, and HIPOs served as software tools. Other approaches that helped in developing the system are system architecture, programming tools, and hardware and software specifications. Several tests were conducted to obtain the desired outputs, which comprises hardware and software components testing, system components testing, integration, and acceptance testing. Administrators account registration tests, fingerprint biometrics registration tests and SMS notification tests, and fingerprint biometrics in-out test and SMS notification tests were also done. The results shown in the tables have proven that the system performs its functions well.

Therefore, based on the methods and tests conducted, it was proven that the project system operates its intended function, and it is an effective system in monitoring student attendance with real-time SMS notification. The researchers found out that the system can run on Windows 7 or higher versions of the Windows Operating System and that the system software is easy to use and understood by its intended user. It performs its functions systematically and beneficial in monitoring attendance and notifying parents in real-time. Moreover, aside from being an accurate system in monitoring attendance 
and informing the parents/guardian on real-time using SMS technology, its saves paper to help save the resources from the environment since the system is a paperless process.

\section{REFERENCES}

[1] Y. Sui, X. Zou, and E. Y. Du, "Biometrics-based authentication: A new approach," Proceedings International Conference on Computer Communications and Networks, ICCCN, pp. 1-2, 2011.

[2] S. Rao and P. K. J. Satoa, "An Attendance Monitoring System Using Biometrics Authentication," International Journal of Advanced Research in Computer Science and Software Engineering, vol. 3, no. 4, pp. 379-383, 2013.

[3] K. A. M. Oloyede, A. Adedoyin, "Fingerprint Biometric Authentication for Enhancing Staff Attendance System," International Journal of Applied Information Systems (IJAIS), vol. 5, no. 3, pp. 19-24, 2013.

[4] A. K. Jain, "On The Uniqueness of Fingerprints," Sackler Colloquium on Forensic Science: The Nexus of Science and Law, National Academy of Sciences., p. 31, 2005.

[5] K. S. Adewole, S. O. Abdulsalam, R. S. Babatunde, T. M. Shittu, and M. O. Oloyede, "Development of Fingerprint Biometric Attendance System for Non-Academic Staff in a Tertiary Institution," Computer Engineering and Intelligent Systems, vol. 5, no. 2, pp. 62-70, 2014.

[6] R. Cappelli, D. Maio, D. Maltoni, J. L. Wayman, and A. K. Jain, "Performance evaluation of fingerprint verification systems," IEEE Transactions on Pattern Analysis and Machine Intelligence, vol. 28, no. 1, pp. 3-17, 2006.

[7] O. Shoewu and O. A. Idowu, "Development of Attendance Management System using Biometrics .," The Pacific Journal of Science and Technology, vol. 13, no. 1, pp. 300-307, 2012.

[8] B. K. P. Mohamed and C. V Raghu, "Fingerprint Attendance System for classroom needs," 2012 Annual IEEE India Conference (INDICON), pp. 433-438, 2012.

[9] S. Badhe, K. Chaudhari, S. Kale, and T. Mane, "Smart attendance management system using it," International Journal of Computer Applications, pp. 10-14, 2016.

[10] U. Tiwari, T. D. Diwan, and N. Sahu, "Save green, go green through paperless," International Journal of Recent Trends in Engineering and Research, vol. 03, no. 01, pp. 64-70, 2016.

[11] B. Gaille, "Paper Consumption Facts," 31 Insane Paper Consumption Statistics, pp. 1-13, 2017.

[12] R. C. So, "Dead trees: How much are we consuming?," The Manila Times, pp. 1-5, 2016.

[13] T. Faulkner, "Save Paper This School Year," ecori news, pp. 4-6, 2018.

[14] M. W. Flamm, “'Going Paperless': The Case for Electronic Submission of Student Work," College Teaching, vol. 62, no. 1, pp. 1-2, 2014.

[15] H.A. Chopra, N. Goel, M. Hemani, and H. Virmani, "Repurposing a word processing document to save paper and ink," 2010.

[16] S. De Bonis and N. De Bonis, "Going Green: Managing a Paperless Classroom," US-China Education Review A, pp. 83-87, 2011.

[17] E. B. Panganiban, "Microcontroller-based Wearable Blood Pressure Monitoring Device with GPS and SMS Feature through Mobile App," International Journal of Emerging Trends in Engineering Research, vol. 7, no. 6, pp. 32-35, 2019.

[18] E. B. Panganiban, "Automated hazardous gas detecting robot using wireless sensor networks with GSM-SMS alert and fire control system for households," International Journal of Advanced Trends in Computer Science and Engineering, vol. 8, no. 3, pp. 804-809, 2019.

[19] I. T. Plata, E. B. Panganiban, B. B. Bartolome, F. E. R. Labuanan, and A. C. Taracatac, "A Concept of Cassava Phytoplasma Disease Monitoring and Mapping System using GIS and SMS Technology," International Journal of Advanced Trends in Computer Science and Engineering, vol. 8, no. 6, pp. 3357-3361, 2019.

[20] A. Tantak, A. Sudrik, A. Kale, R. Mehetre, and P. M. S. S. Pophale, "Face Recognition for E-Attendance for Student and Staff," IOSR Journal of Computer Engineering, vol. 19, no. 02, pp. 89-94, 2017.

[21] Y. Mittal, A. Varshney, P. Aggarwal, K. Matani, and V. K. Mittal, "Fingerprint biometric based Access Control and Classroom Attendance Management System," 12th IEEE International Conference Electronics, Energy, Environment, Communication, Computer, Control: (E3-C3), INDICON 2015, pp. 3-5, 2016.

[22] F. Parvinzamir, "Fingerprint-based Student Attendance Register," Thesis, p. 91, 2012.

[23] F. Siddiqui, "Wireless Attendance Management System Based On Fingerprint Recognition," Imperial Journal of Interdisciplinary Research, vol. 3, no. 5, pp. 299-301, 2017.

[24] M. P. Potadar, V. V Marathe, A. S. Khose, and L. A. Kotkar, "Biometric Attendance Recording and Communication System," International Journal of Innovations in Engineering and Technology (IJIET), vol. 5, no. 2, pp. 230-234, 2015.

[25] P. Corcoran et al., "Student Attendance System Based On Fingerprint Recognition and One-to-Many Matching," 2nd International Workshop on Evolving Security and Privacy Requirements Engineering, ESPRE 2015 Proceedings, vol. 1, no. 19, pp. 58-60, 2012. 
[26] N. K. M. K. D. A. S. D. R. Pal, "Study of Implementing Automated Attendance System Using Face Recognition Technique," International Journal of Computer and Communication Engineering, vol. 1, no. 2, pp. 100-103, 2012.

[27] R. Subban and D. P. Mankame, "A Study of Biometric Approach Using Fingerprint Recognition," Lecture Notes on Software Engineering, vol. 1, no. 2, pp. 209-213, 2013.

[28] J. C. Dela Cruz, A. C. Paglinawan, M. I. R. Bonifacio, A. J. D. Flores, and E. V. B. Hurna, "Biometrics based attendance checking using Principal Component Analysis," IEEE Region 10 Humanitarian Technology Conference, R10-HTC 2015 - co-located with 8th International Conference on Humanoid, Nanotechnology, Information Technology, Communication and Control, Environment and Management, HNICEM 2015, pp. 1-2, 2016.

[29] I. T. Plata, E. B. Panganiban, and B. B. Bartolome, "A Security Approach for File Management System using Data Encryption Standard ( DES ) algorithm," International Journal of Advanced Trends in Computer Science and Engineering, vol. 8, no. 5, 2019. 